\title{
BUDAYA LOKAL DI ERA GLOBAL
}

Naomi Diah Budi Setyaningrum

FKIP-Universitas PGRI Palembang

Jl. Jend A. Yani Lorong Gotong RoyongNo. 9/10, 13 Ulu,

Seberang Ulu II, Kota Palembang

naomibudi1212@gmail.com

\begin{abstract}
ABSTRAK
Budaya lokal akan lebih bermakna karena mampu mendorong semangat kecintaan pada kehidupan manusia dan alam semesta. Sementara teknologi sebagai hasil kebudayaan yang bersifat fisik tanpa spritualitas nilai-nilai yang terkandung dalam adat istiadat, agama, kesenian akan kehilangan fungsi untuk meningkatkan kualitas hidup manusia. Nilai-nilai, norma, etika yang terkandung dalam aturan adat tercermin dalam budaya lokal semestinya merupakan referensi -referensi yang bermanfaat di era globalisasi. Menggunakan data kualitatif penelitian ini dianalisis secara deskkriptif. Merujuk pada pemikiran Alvin Boskoff menunjukan bahwa faktor-faktor yang menjadi tantangan bagi Budaya Lokal adalah perubahan tata nilai-nilai budaya dalam masyarakat, serta matinya bentuk-bentuk seni tradisi dibeberapa wilayah Nusantara, yang disebabkan oleh teknologi di era global. Budaya lokal adalah salah satu komponen yang memberikan jati diri kita sebagai sebuah komunitas yang spesial, yang eksis di antara bangsa-bangsa di dunia ini. Maka dipandang perlu menumbuhkan kesadaran bagi generasi muda untuk lebih memahami budaya yang dimilikinya. Dengan cara memberdayakan kearifan lokal yang tumbuh di kantong-kantong budaya di seluruh persada Nusantara.
\end{abstract}

Kata Kunci: Budaya, lokal, perubahan nilai, global.

\begin{abstract}
Local culture will be more meaningful because of being able to push the spirit of love toward human's life and universe. Meanwhile, technology as the physical result of culture that lacks spiritual values if compared to custom, religion and art will lose its function to increase human's life quality. Values, norms and ethics contained in customary rules that are reflected in local culture are indeed useful references in globalization era. This research used qualitative data that were then analyzed descriptively. According to Alvin Boskoff's thought, it shows that factors becoming challenges for local culture are the change of cultural value systems in society and the death of traditional art forms in several areas in Nusantara caused by technology in global era. Local culture is one of components that gives Indonesian identity as a special community that exists among nations in this world. Therefore it's necessary to grow awareness particularly in young generations in order to comprehend more about their culture by empowering local wisdom growing in the cultural areas of whole Nusantara.
\end{abstract}

Keywords: Culture, local, the change of value, global 


\section{PENDAHULUAN}

Globalisasi budaya merupakan "serangkaian proses dimana relasi akal dan budi manusia relatif terlepas dari wilayah geografis". Hal tersebut memunculkan jalinan situasi yang integratif antara akal dan budi manusia di suatu belahan bumi dengan yang lainnya. dari pemahaman tersebut tidak menutup kemungkinan muncul budaya pop yang mengglobal atau disebut dengan global pop culture, yakni budaya tren dalam suatu wilayah yang kemudian dipopulerkan dan diterima hingga ke taraf dunia atau lingkup global. Hal tersebut sesuai pendapat kaum hiperglobalis bahwa globalisasi budaya adalah homogezination of the world under the auspices of American popular culture of western consumerism in general . ( I.Made Gede Arimbawa, 2011:175), bahwa globalisasi budaya adalah proses homogenisasi dunia dengan mengusung kemasan budaya populer Amerika. Kondisi tersebut jelas dapat dilihat dan dinilai dari penekanan konsumsi terhadap budaya Barat pada umumnya, sehingga muncul istilah Westernisasi yang digunakan sebagai simbol terhadap sifat konsumerisme. Dalam konteks tersebut dapat diartikan bahwa ' budaya Barat" adalah budaya yang diperjual belikan sementara masyarakat dunia pada umumnya adalah konsumen atau penikmat. Sebagai contoh konsumsi terhadap bentuk pemerintahan atau sistem politik, mekanisme pasar, aliran musik gaya hidup makanan, seni, desain pakaian dan sebagainya. Paham hiperglobalis tersebut tidak terlepas dari sifat-sifat yang cenderung berorientasi pada ekonomi kapitalis.

Ada anggapan bahwa globalisasi mengancam dan dapat merusak tatanan kehidupan heterogenitas budaya lokal dengan mengabaikan keragaman dan kearifan lokal untuk menuju pada universalitas. Kedua paham tersebut merupakan situasi yang dikotomi dan dilematis serta tarik menarik. Yasraf Amir Piliang (2005 13), bila homogenisasi daya tariknya lebih kuat, maka budaya lokal akan terseret ke dalam arus globalisasi, sehingga merupakan ancaman terhadap kesinabungan, eksistensi dan kehilangan identitas. Sedangkan bagi budaya lokal jika tidak mengadakan pengembangan, maka peluang penciptaan keunggulan budaya lokal tidak dilakukan, maka budaya etnik Nusantara justru dimanfaatkan oleh pihak luar yang berkepentingan, berupa "pencurian" kemudian dimodifikasi disesuaikan dengan kepentingan ekonomi kapitalis global.

Tidak ada yang perlu dikhawatirkan secara berlebihan sebab globalisasi budaya ada ambiguitas yang melekat, di satu sisi saling kenal mengenal budaya antar bangsa 
dan di sisi lain, ada kekuatan untuk memperthankan identitas lokal. Salah satu contoh mengenai kekuatan budaya lokal untuk membentengi identitas etnik dengan ikatan primordial, yakni dalam penggunaan bahasa Indonesia.

Globalisasi membawa pengaruh pada perubahan dalam diri masyarakat dan lingkungan hidupnya serentak dengan laju perkembangan dunia, sehingga terjadi pula dinamika masyarakat. Terjadi perubahan sikap terhadap nilai-nilai budaya yang sudah ada. Sehingga terjadilah pergeseran system nilai budaya yang membawa perubahan pula dalam hubungan interaksi manusia di dalam masyarakat.

Dampak globalisasi dan kemajuan dibidang tekknologi komunikasi yang masuk secara tidak disadari membawa dampak terhadap intensitas kontak budaya antar suku maupun dengan kebudayaan dari luar. Khususnya dengan kontak budaya dengan kebudayaan asing itu bukan saja intensitasnya menjadi besar, tetapi juga penyebarannya berlangsung dengan cepat dan luas jangkauannya. Terjadilah perubahan orientasi budaya yang kadangkadang menimbulkan dampak terhadap tata nilai masyarakat.

Fenomena perubahan dan pergeseran budaya yang diakibatkan oleh pengaruh global ini sangat menarik untuk diungkap. Penelitian ini lebih difokuskan pada permasalahan tantangan budaya Nusantara dalam menghadapi era global.

\section{PEMBAHASAN}

\section{Budaya Lokal di Era Global}

Budaya lokal yang hidup di tengah masyarakat biasanya lahir dari dorongan spritual masyarakat dan ritus-ritus lokal yang secara rohani dan material sangat penting bagi kehidupan sosial suatu lingkungan masyarakat desa. Budaya lokal memiliki hubungan yang sangat erat dngan masyarakat di suatu lingkungan dengan seluruh kondisi alam di lingkungan tersebut. Ia ditampilkan dalam berbagai upacara adat suatu desa, bersih desa, misalnya dilakukan untuk menghormati roh nenek moyang sebagai penunggu desa. Maksud upacara agar desa dilimpahi kesejahteraan oleh penunggu tersebut. Terlepas dari kepercayaan tersebut, upacara yang dilakukan dengan cara membersihkan desa menghasilkan dampak lingkungan yang baik. Apabila desa bersih dari limbah apapun maka alirannya yang berfungsi mengaliri persawahan akan lancar. Lingkungan desa akan menjadi bersih dan sehat sehingga panen menjadi baik.

Budaya lokal yang ditampilkan dalam upacara adat tersebut mempunyai fungsi yang sangat penting. Memberi dorongan solidaritas kepada masyarakat 
dalam rangka mempersatukan niat, kemauan dan perasaan mereka dalam menjalankan upacara tersebut. Budaya lokal sebagaimana seni yang lain secara historis selalu memiliki suasana kontekstual, dimana seni tidak bisa dilihat tanpa fungsi tertentu bagi sebagian masyarakat masingmasing budaya.

Rupanya upacara adat dan budaya lokal yang menjadi kesatuan budaya lingkungan tersebut di samping merupakan ekspresi spritualitas, di dalamnya terkandung suatu budaya dalam rangka mengarahkan masyarakat pada kepedulian, pemeliharaan dan pelestarian alam lingkungan. Justru sangat besar kemungkinan landasan spritual yang ditanamkan nenek moyang tersebut memang dimaksudkan sebagai upaya pelestarian alam lingkungan yang akan menjaga kestabilan, kesehatan, lingkungan, dan memberi dorongan perilaku manusia dalam menyikapi kehidupan dan lingkungannya. Sikap budaya ini menjadi utuh ketika upaya peningkatan kualitas hidup dalam sistem ekonomi dan teknologi tidak mengganggu harmoni antara hidup manusia dan kehidupan alam semesta.

\section{Matinya Bentuk-Bentuk Kesenian Tradisional/Kearifan Lokal dikarenakan Dampak Teknologi}

Budaya lokal kini menghadapi tantangan global yang sangat serius, termasuk di kota-kota yang memiliki predikat Urban, Metropolitan, maupun Cosmopolitan. Kita sudah jarang menemukan Gambang Kromong, Rebana Ketimpring, Rebana Biang, Tajidor, dan lain sebagainya di kota Metro Politan Jakarta; Kidungan, Mamaca, Ngremo, dan sebagainya di Surabaya. Di Sumatera khususnya kita masih menemukan Tembang Batang Hari Sembilan, Sastra Tutur, Teater Tradisional Dul Muluk. Sejauh pengamatan, bentuk kesenian ini mengalami pasang surut dalam kehidupannya, bahkan ada beberapa yang telah mengalami mati suri.

Aplikasi teknologi modern di kalangan masyarakat petani, sedemikian rupa telah mengubah sikap mental perilaku masyarakat petani, Hadirnya teknologi modern di era global lambat laun juga telah mengubah kepercayaan petani terhadap penguasa padi "Sangyang Sri"' (Dewi Sri nama Dewi Padi bagi masyarakat Jawa).. Sehingga kesehatan dan hasil panen padi sekarang bukan karena anugrah "Sangyang Sri",, melainkan karena hasil teknologi modern seperti mesin giling, mesin bajak sawah, pupuk sintetis obat inteksida, yang semuanya diperoleh dengan uang. Maka hal tersebut sangatlah berpengaruh terhadap sikap atau kehidupan berkesenian masyarakat petani. 
Kekayaan seni tradisi dengan beragam jenis dan bentuknya adalah hasil karya masyarakat petani. Bahkan seni pertunjukan Istana (Kraton) banyak juga yang berasal dari masyarakat petani, hal tersebut seperti yang diungkapkan oleh Roestopo dalam tulisannya yang berjudul Seni Pertunjukan masyarakat petani dan Teknologi, mengungkapkannya sebagai berikut:

Dahulu ada kepercayaan yang diyakini oleh masyarakat Kraton, (Surakarta), apabila gending "Anglir Mendung”, disajikan akan mempengaruhi awan dan akibatnya turun hujan. Sebaliknya "Gending Pacul Gowang", apabila disajikan dapat menghentikan hujan angin yang meresahkan. Kepercayaan seperti ini juga dimiliki masyarakat petani pedesaan, Ujungan atau Ujung, adalah tari perang antara dua laki-laki (ada beberapa pasang) yang saling mencambuk atau menggebug dan menangkis di lapangan terbuka atau di tengah sawah, disaksikan oleh seluruh warga desa yang masing-masing membawa sesaji. Di beberapa puluh tahun yang lalu dapat dilihat di Purbalingga (Jateng), Trenggalek (Jatim), Madura dan Flores, Tari ini merupakan tari ritual untuk meminta hujan. Penari yang terluka kena cambuk dengan darah tercecer ke atas tanah merupakan keberhasilan dari ritual itu. Karena darah yang menetes ke atas tanah itu dipercaya sebagai jaminan turunnya hujan. Tari Ritual ini sudah tidak diperlukan lagi ketika bendungan dan saluran irigasi dibangun. Kekeringan diupayakan dengan membuat hujan buatan yaitu dengan menyuntikan zat nitrogen kea wan dengan pesawat terbang. ${ }^{1}$
Pendapat di atas dapat disimpulkan bahwa jika kita mau jujur, kekayaan seni tradisi adalah sebagian besar hasil karya masyarakat petani, begitu pula seni pertunjukan Istana dapat dihubungkan Hal| 106 selalu berhubungan dengan kepercayaan sebagai sarana ritual. Hal tersebut juga diperkuat oleh pernyataan Ben Suharto dalam Konsep Mandalanya yang mengupas tentang tata hubungan manusia dengan alam dan Sang Pencipta, dalam paparannya diungkapkan tentang Konsep Mandala antara lain:

$$
\text { Konsep Mandala dalam Budaya }
$$
Nusantara menjelaskan pandangan masyarakat terhadap hubungan mikrokosmos dan makrokosmos, Jose and Mariam Aguelles mengkaitkan dengan bentuk ritual pada konsep mandala (mandala conseps) yaitu hubungan interaksi yang kemudian membentuk satu kesatuan dan keseimbangan kosmos "centering". Rustopo, 2002:6). Konsep mandala membentuk keseimbangan, keselarasan dan kesatuan dan masing-masing memberi kekuatan/energi secara sentral (centering of life). Masyarakat Nusantara mengenal sistem waktu dalam kosmos, hubungan yang tak terpisahkan antara dirinya dengan alam semesta. Pandangan ini oleh masyarakat Jawa dikenal dengan keblat papat ke lima pancer, istilah dalam kosmologi Jawa. Keblat papat kelima 
pancer dalam konsep Mandala dimaksu adalah (1) bumi dilambangkan dengan warna hitam dengan arah utara menunjukkan nafsu lauwamah. (2). Api, yang dilambangkan dengan warna merah dengan arah Selatan bersifat nafsu amarah. (3) Angin: dilambangkan dengan warna kuning dengan arah Barat menunjukkan nafsu supiah, artinya birahi, menimbulkan watak rindu, membangkitkan keinginan, kesenangan dan sebagainya. (4). Air dilambangkan dengan warna putih dengan arah Timur bersifat mutmainah jujur artinya ketentraman, punya watak kebaikan, tanpa mengenal batas kemampuan. (5). Tengah (batin/Jiwa kita): dengan posisi tengah dilambangkan dengan warna hijau bersifat kama (budi), merupakan penggambaran subyek dari nafsu batin manusia. Apabila kita mampu mengendalikan 4 nafsu tersebut maka kita akan mendapatkan Sinar terang/sinar kemuliaan Tuhan. ( Darsono $2013: 4)$.

Jika kita pahami dewasa ini nilai-nilai kearifan lokal yang dimiliki bangsa ini lambat laun telah memudar dikarenakan kemajuan teknologi yang ada yang disebabkan pengaruh dampak teknologi di era global sekarang ini. Hal tersebut bisa dilihat/ditandai dengan semakin sulitnya menjumpai bentuk-bentuk seni pertunjukan tradisional yang difungsikan sebagai sarana ritual, akan tetapi bentuk-bentuk pertunjukan sekarang ini lebih berfungsi sebagai sarana hiburan semata. Dengan kata lain bentuk-bentuk seni pertunjukan yang ada sudah kehilangan nilai budaya atau kandungan nilainya telah berubah.

\section{Perubahan Tata Nilai di Masyarakat}

Secara tradisional, bangsa-bangsa di wilayah Timur, pada umumnya memiliki orientasi nilai budaya yang bersifat mistis, magis, kosmis dan religius. Bangsa yang berorientasi pada nilai Budaya seperti ini, secara umum ingin hidup menyatu dengan alam karena mereka menyadari bahwa dirinya merupakan bagian dari alam. Alam sebagai sumber kehidupan memiliki kekuatan atau potensi tertentu yang memberi atau mempengaruhi hidupnya (Ratna Kutha, Nyoman 2007:63). Oleh karena itu segala sesuatunya diarahkan untuk menuju kehidupan yang harmoni dengan alam dan berusaha menghindari segala hal yang berakibat bertentangan dengan atau melawan alam. Dalam pandangan seperti itu alam adalah makrokosmos dan manusia adalah mikrokosmos. Oleh karena itu jika ingin kehidupan ini sejahtera dan selamat, maka manusia sebagai mikrokosmos haruslah berusaha menyatukan, menyelaraskan atau mengharmoniskan kehidupannya dengan alam sebagai makrokosmos.

Karya-karya seni tradisional yang dihasilkan baik seni rupa, seni musik 
maupun bentuk seni yang lainnya ketika terjadi peristiwa upacara atau ritual seperti halnya daur hidup, bersih desa, pesta panen, minta hujan ataupun sedekah bumi. Tari dan seni pertunjukan yang lainnya sering dikemas untuk suatu kepentingan peristiwa budaya tertentu, misalnya dalam berbagai upacara adat atau keagamaan. Karena kegiatan estetik semacam itu lebih dirasakan sebagai aktivitas yang bersifat mistis atau religius. Hal tersebut dapat dilihat dari beberapa bentuk kesenian Nusantara.

Globalisasi tanpa disadari telah membawa perubahan tata nilai di masyarakat. Perubahan itu nampak terjadinya pergeseran sistem nilai budaya serta sikap dan pandangan yang telah berubah terhadap nilai-nilai budaya. Pengaruh global tanpa disadari telah menimbulkan mobilitas sosial, yang diikuti ol eh hubungan tata nilai budaya yang bergeser dalam kehidupan masyarakat.

Dampak globalisasi dan kemajuan di bidang tekhnologi komunikasi yang masuk secara tidak disadari membawa dampakterhadap intensitas kontak budaya antar suku maupun dengan kebudayaan dari luar. Khususnya dengan kontak budaya dengan kebudayaan asing itu bukan saja intensitasnya menjadi besar, tetapi juga penyebarannya berlangsung dengan cepat dan luas jangkauannya. Terjadilah perubahan orientasi budaya yang kadangkadang menimbulkan dampak terhadap tata nilai masyarakat.

Menghadapi era globalisasi, maka kita dituntut mampu mengembangkan dan Hal| 108 memanfaatkan kekayaan budaya yang memiliki (kearifan-kearifan lokal/ lokal genius). Oleh karena itu pentingnya memahami budaya-budaya daerah yang dimiliki bangsa ini serta mengembangkan karya-karya seni melalui pendekatan filsafat Nusantara yang dikenal sebagai Filsafat Mistika (2012:2).

Pemaparkan di atas menjelaskan bahwa mempelajari Filsafat Mistika (Mystical Philosophy), adalah mencari kesempurnaan sejati (ngudi kasampurnan jati). Pandangan yang menekankan pada ketentraman batin, keselarasan dan keseimbangan, disertai dengan sifat ikhlas terhadap segala peristiwa yang terjadi, sambil menempat individu di bawah masyarakat dan masyarakat di bawah alam semesta (hubungan makrokosmos dan mikrokosmos). Yakni barang siapa hidup selaras dengan dirinya sendiri, akan selaras dengan masyarakatnya, maka hidup selaras juga dengan Tuhannya dan mampu menjalankan hidup yang benar.

Ahimsa Putra berpendapat bahwa,"Kearifan lokal adalah kebiasaan suatu komunitas yang mengandung tata nilai, sumber moral yang dihargai oleh 
komunitas itu. Kearifan lokal juga memiliki pengertian sebagai perangkat pengetahuan dan praktek yang dapat digunakan untuk menyelesaikan persoalan/kesulitan yang dihadapi dengan cara yang baik, benar dan bagus (2009 : 2). Kearifan lokal (local wisdom), secara singkat diartikan sebagai kebijaksanaan lokal, sedangkan secara filosofis, kearifan lokal dapat diartikan sebagai sistem pengetahuan masyarakat lokal yang bersifat empirik dan pragmatis. Bersifat empirik karena hasil pengolahan masyarakat secara lokal, dan berangkat dari fakta-fakta yang terjadi di sekeliling kehidupan masyarakat serta pragmatis, karena konsep yang terbangun sebagai hasil pengolahan fikir dalam sistem pengetahuan bertujuan untuk memecahkan masalah sehari-hari.

Kearifan lokal merupakan bagian dari kebudayaan yang bernilai tinggi, atau mengandung nilai-nilai yang luhur. Budaya yang tercipta membentuk serta menumbuhkan identitasnya sebagai manusia seutuhnya. Setiap orang memiliki identitas yang dibangun oleh budayanya, dan kearifan lokal hadir dalam budaya yang membentuk identitas manusia itu.

Indonesia memiliki wilayah yang luas, serta memiliki kekayaan budaya dan dan kearifan yang tersebar di seluruh pelosok tanah air di Indonesia. Perubahan kebudayaan yang berakibat pada perubahan pola fikir, gaya hidup, dan kebudayaan masyarakat yang berdampak pada perubahan kearifan lokal, terjadi pergeseran atau mulai ditinggalkannya kearifan lokal..

Pemberdayaan kearifan lokal dalam pengembangan kebudayaan daerah perlu dilakukan karena hilangnya kearifan lokal di Indonesia bisa berdampak ketahanan budaya dan terhambatnya pencapaian tujuan nasional. Sementara itu pengembangan kebudayaan daerah ditekankan pula pada keberlanjudan kehidupan seni tradisi, baik kesenian keraton maupun kesenian rakyat. Upaya pelestarian dan pengembangan melalui pendidikan formal dan non formal.

Pengembangan budaya yang secara terus menerus dilakukan dapat mendukung keberlangsungan kehidupan budaya, yang berpengaruh dan berkarakter, identitas, dan integritas bangsa Indonesia. Hal itu menjadi salah satu faktor yang menentukan kekuatan atau ketangguhan budaya Indonesia terhadap pengaruh budaya dari dalam maupun dari luar atau disebabkan oleh faktor internal dan eksternalnya. Menurut Sedyawati, ketahanan Budaya diartikan sebagai kemampuan sebuah kebudayaan untuk mempertahankan jati dirinya, tidak dengan menolak semua unsur asing, melainkan dengan menyaring, memilih, dan jika perlu memodifikasi unsur-unsur budaya luar, sedemikian rupa 
sehingga tetap sesuai dengan karakter dan citra bangsa (Edi Sedyawati 2007:7).

Untuk menghadapi pengaruh budaya asing itu, maka diperlukan kreatifitas atau daya kreatif dan kritis untuk menanggapi segala pengaruh dalam kehidupan. Kreativitas itu pada dasarnya terdapat pada semua masyarakat, baik yang konservatif maupun progresif. Pada kenyataannya budaya Indonesia selalu berubah sesuai dengan zamannya. Selain itu, dapat pula meningkatkan kreativitas seniman agar produktif di dalam menciptakan karyakarya seni, menyediakan sarana dan prasarana.

\section{Pemahaman dan Pemberdayaan}

\section{Kearifan Lokal}

Untuk menjawab permasalahan tantangan global maka sangatlah penting mengembalikan kesadaran masyarakat betapa pentingnya memahami akan budaya yang dimiliki bangsa ini (Nusantara). Pentingnya pemberdayaan Kearifan lokal juga dapat menciptakan, harmonisasi kehidupan tetap terjaga, dapat menuntun masyarakat untuk selalu bersikap dan berperilaku arif terhadap lingkungan. Kearifan terhadap lingkungan dapat dilihat dari bagimana perlakuan masyarakat terhadap benda-benda, tumbuhan, hewan dan apapun yang berada di sekitarnya. Perlakuan ini melibatkan penggunaan akal budi sehingga dari perlakuan-perlakuan tersebut tergambar hasil dari aktivitas budi atau kearifan lokal.

Pentingnya menanamkan kepada masyarakat tehadap kearifan lokal tidak hanya masalah fisik, akan tetapi juga nilainilai budaya luhur yang harus dilestarikan di dalam kehidupan masyarakat. Kesadaran masyarakat akan mengubah persepsi mereka terhadap kearifan lokal dan kesadaran terhadap keuntungan memilki kearifan lokal. Kesadaran itu dapat mengarahkan masyarakat untuk melaksanakan kembali berbagai aktivitas yang merupakan bagian dari kearifan lokal. Kearifan lokal dapat memperkaya kehidupan masyarakat dan juga dapat memberikan pengalaman yang mendalam dan menjadikan interaksi dan hubungan antara anggota masyarakat lebih harmonis, penuh dengan saling penghargaan dan keakraban. Adapun dampak positiv dalam kehidupan masyarakat mereka akan lebih bahagia dan sejahtera

Sebagai pekerja seni/pendidik seni/seniman, maka dituntut memiliki kepiawaian di dalam berolah seni, sehingga diharapkan kemampuan budaya lokal/setempat dapat disejajarkan dengan kebudayaan modern. Kesenian adalah salah satu bagian vital dari kebudayaan. Maka kebudayaan diharapkan dapat memberikan kontribusi dalam membangun etos kerja dan daya kreasi. Maka selayaknya seni 
seharusnya dapat berkembang secara alami baik dalam kontek tradisional maupun modern.

Menghadapi era globalisasi, maka kita dituntut mampu mengembangkan dan memanfaatkan kekayaan budaya yang memiliki (kearifan-kearifan local/ local genius). Oleh karena itu pentingnya memahami budaya-budaya daerah yang dimiliki bangsa ini serta mengembangkan karya-karya seni yang diharapkan mampu menjawab tantangan budaya di era global.

\section{Kondisi Kearifan Lokal Yang diharapkan}

Kearifan lokal yang merupakan bagian dari kebudayaan lokal atau kebudayaan daerah, sebagai sesuatu yang dibedakan dengan kebudayaan nasional. Identitas budaya bangsa Indonesia (dalam makna kebudayaan nasional Indonesia) mempunyai dua sisi yaitu segala sesuatu yang diciptakan dalam konteks ke Indonesiaan. Maknanya adalah sejak masa pergerakan nasional, hingga kini; dan puncak-puncak budaya yang diangkat dari berbagai tradisi suku-suku bangsa yang ada di Indonesia, yang diterima sebagai milik bersama seluruh bangsa Indonesia. Adapun yang dihadapi masa kini adalah bahwa kedua substansi kebudayaan Indonesia itu kini cenderung agak kurang dikenal oleh khalayak ramai, termasuk oleh generasi muda, hal ini terjadi dikarenakan masuknya budaya popular yang berkonotasi terkait sebagai bagian dari Budaya Global (Edi Sedyawati $2007: 6$ ).

Pengembangan budaya lokal Hal| 111 dilakukan dengan menanamkan kesadaran terhadap pentingnya kebudayaan dan kearifan lokal bagi kehidupan masyarakat. Dengan kesadaran itu, maka diharapkan masyarakat luas merasa memiliki dan bangga terhadap kebudayaannya. Hal tersebut tentunya akan lebih efektif, apabila dilandasi oleh kesadaran untuk menjadikan budaya sebagai bagian dari identitas, jatidiri, dan ekspresi serta untuk pengkayaan budaya daerah. Kesadaran bahwa kebudayaan adalah karakter bangsa yang mengandung nilai-nilai luhur dan mendorong masyarakat untuk berupaya mengembangkan kebudayaannya.

\section{PENUTUP}

Keberagaman budaya lokal dihadapkan pada masalah pada satu sisi dan modernisasi di sisi lain. Bagi seniman sebagai ujung tombak pembaharuan, maka tidak ada jalan kecuali melihat ke depan namun hal ini tidak berarti kita hanya begitu saja menyepelekan nilai-niali lokal. Kita harus berkembang dari kekayaan yang ada.

Apapun tantangan yang dihadapi Budaya Nusantara di era global, maka sangatlah penting menumbuhkan kesadaran 
bagi generasi muda untuk lebih memahami budaya yang dimiliki bangsa ini dengan mencintainya, memahami nilai nilai yang terkandung serta melestarikan. keberadaannya dengan cara memberdayakan kearifan lokal yang tumbuh di kantong-kantong budaya di seluruh persada Nusantara.

\section{KEPUSTAKAAN}

Boskoff, Alvin ."Recent Theories of Social Change" dalam Weaner J. Cahnman \& Alvin Boskoff (ed.),Sociologi and History: Theory and Research, London: The Free Press of Glencoe, 1964.

Darsono, Sony Kartika. 2013.”Budaya Nusantara Pendekatan Filsafat Mistika" (Mystical Philosophy).

I.Made Gede Arimbawa, 2011, "Basis Pengembangan Desain Produk Keramik pada Era Pasar Global" Mudra Jurnal Seni Budaya Volume 26 No 2 Juli 2012 ISSN 0854-3461.

Kutha Ratna, Nyoman, 2007.“ Estetika Sastra dan Budaya”. Yogyakarta, Penerbit, Pustaka Pelajar.

Yasraf Amir Piliang 2005, 'Menciptakan Keunggulan Lokal untuk Merebut Peluang Global, Sebuah Pendekatan Kultural" Seminar " Membedah Keunggulan Lokal dalam Konteks Global" tgl 26 Juli 2005 ISI Denpasar.

Sedyawati, Edi. 2007. Keindahan dalam Budaya Buku 1 Kebutuhan Membangun Bangsa Yang Kuat.Jakarta: Wedatama Widya Sastra.
Sedyawati, Edi. 2008. Keindonesiaan dalam Budaya Buku 2 Dialog Budaya: Nasional dan Etnik, Peranan Industri Budaya dan Media Masa, Warisan Budaya, dan Pelestarian Dinamis.Jakarta: Wedatama Widya Sastra.

Soedarsono, Nani. 2016. "Pembudayaan Pancasila Melalui Kearifan Lokal dalam Memperkuat Identitas Budaya Bangsa" dalam Bacaan Budaya Bende, Vol 6 No 2 Juni 2011. 